\title{
TrkB and TrkC neurotrophin receptors cooperate in promoting survival of hippocampal and cerebellar granule neurons
}

\author{
Liliana Minichiello and Rüdiger Klein ${ }^{1}$ \\ European Molecular Biology Laboratory, Meyerhofstrasse 1, D-69117 Heidelberg, Germany
}

The Trk family of protein tyrosine kinases $(T r k A / B / C)$ are receptors for neurotrophins, a family of closely related proteins that are important physiological regulators of the survival of specific neurons within the peripheral nervous system (PNS) of vertebrates. In contrast to the PNS, brains of mutant mice deficient in a single neurotrophin or Trk receptor species do not show signs of major cell loss. However, in double mutant mice, we now show that reducing the expression of both TrkB and TrkC causes massive cell death of postnatal hippocampal and cerebellar granule neurons. Kinetic analysis of neuronal death in the hippocampus showed that dentate gyrus granule neurons become dependent on TrkB and TrkC after the first postnatal week, shortly after the period of naturally occurring cell death, indicating a role of these receptors in supporting postmitotic neurons. Correlating with the loss of granule cells, the number of mossy fibers projecting to CA3 pyramidal neurons was markedly reduced in mice carrying mutant trkB/trkC alleles, demonstrating impairment of excitatory pathways in the hippocampus. In the cerebellum, TrkB and TrkC receptors were specifically required for premigratory granule neurons located in the external granule layer. In contrast, cerebellar Purkinje cells were found to be poorly differentiated, but showed no signs of increased cell death. These results provide in vivo evidence that neurotrophins are essential physiological survival factors for specific central neurons. Moreover, they suggest that central, in contrast to peripheral, neurons are capable of using more than one neurotrophin/Trk receptor signaling pathway to stay alive.

[Key Words: Neurotrophins; Trk; receptor tyrosine kinase; hippocampus; dentate gyrus; cerebellum; apoptosis]

Received May 29, 1996; revised version accepted September 30, 1996.

Limited amounts of neurotrophic factors are thought to be the key determinants to regulate the number of surviving neurons during development. The best-studied family of neuronal survival factors are the neurotrophins, including nerve growth factor (NGF), brain-derived neurotrophic factor (BDNF), neurotrophin-3 (NT3), NT4/5, and NT6, the latter apparently being specific for fish (Götz et al. 1994; Lewin and Barde 1996). The effects of neurotrophins are primarily mediated by protein-tyrosine kinase receptors of the Trk family, with TrkA being a receptor for NGF, TrkB being a receptor for both $\mathrm{BDNF}$ and NT4/5, and TrkC being the preferred receptor for NT3, which can also interact with lower efficiency with TrkA and TrkB (Davies et al. 1995). Recent studies in neurotrophin and Trk receptor knockout mice have revealed their critical functions during neural development. One important conclusion from these genetic experiments was that many peripheral neurons depend for

\footnotetext{
${ }^{1}$ Corresponding author.
}

their survival on a supply of a single type of neurotrophin from the tissues they innervate (Davies 1994a; Klein 1994; Snider 1994; Barbacid 1995). In contrast, although previous studies have demonstrated survival-promoting effects of exogenous neurotrophins on central nervous system (CNS) neurons (Eide et al. 1993; Henderson et al. 1993; Arenas and Persson 1994), essentially all neurotrophin-responsive CNS neurons appear to survive in absence of a single neurotrophin or its cognate receptor (Farinas and Reichardt 1996; Henderson 1996). It is therefore currently hypothesized that, unlike peripheral neurons, central neurons may have access to other neurotrophic factors that can compensate for these deficiencies in vivo. Considering that neurotrophins have been implicated as regulators of neuronal differentiation and as modulators of synaptic efficacy (Cabelli et al. 1995; Cohen-Cory and Fraser 1995; Kang and Schuman 1995; Thoenen 1995), it is even conceivable that neurotrophins do not have a physiological role in the survival of CNS neurons and serve only as survival factors for peripheral neurons. 
To investigate whether two Trk receptors may have overlapping functions in promoting central neuron survival, we crossed mice carrying loss-of-function alleles of different trk genes (Klein et al. 1993, 1994; Smeyne et al. 1994) to generate mice doubly deficient in pairs of two different Trk receptors. Here we show that during the second postnatal week, TrkB and TrkC receptors are required to prevent apoptosis of at least two CNS neuron populations, hippocampal dentate gyrus and cerebellar granule neurons. In contrast to their action on peripheral neurons, TrkB and TrkC function in a compensatory, redundant fashion indicating that CNS neurons can use more than one neurotrophin/Trk receptor signaling pathway for survival.

\section{Results}

Increased number of pyknotic cells in the dentate gyrus of mice carrying mutant trk $B$ and trk $C$ alleles

None of the double homozygous $\mid \operatorname{trk} A-/-; \operatorname{trk} B-1-$, $\operatorname{trk} A-/-/$;rk $C-/-$, and $\operatorname{trk} B-/-$; trkC-/- mice resulting from crosses of corresponding heterozygotes survived beyond postnatal day 1 (P1). We therefore concentrated our analysis on mice that were homozygous for one mutant trk allele, and heterozygous mutant for a second Trk receptor, for example trk $B-/-$; trk $C+/-$, a considerable fraction of which survived until the end of the second postnatal week. Those genotypes are likely to reveal dosage-dependent genetic interaction between Trk receptor, because their expression is reduced by approximately half in heterozygotes (Klein et al. 1993, 1994). As a morphological hallmark of cells undergoing programmed cell death, we counted pyknotic nuclei, which were recognized either as darkly stained spherical structures with pale or absent cytoplasm or by the presence of darkly stained granules of nuclear chromatin. Analysis of forebrains of P12 double mutant mice revealed a dramatic accumulation of pyknotic nuclei specifically in the hippocampal dentate gyrus of mice carrying mutant $\operatorname{trk} B$ and $\operatorname{trk} C$ alleles (Fig. 1). Whereas among the single mutants, only $\operatorname{trk} B-/-$ mice showed a small (less than twofold) yet significant increase of pyknotic nuclei in the granule cell layer of the dentate gyrus, there were a 14 - and 10 -fold increase in $\operatorname{trk} B-/-; \operatorname{trk} C+/-$ and $\operatorname{trk} B+/-; \operatorname{trk} C-/-$ mice, respectively, compared with wild-type mice (Fig. 2A). In contrast, double heterozygous trkB+/-;trkC+/mice behaved like wild-type mice (data not shown). Moreover, all combinations of double mutant mice involving the mutant $\operatorname{trk} A$ allele $\operatorname{trk} A-/-$; trk $B+/-$, $\operatorname{trk} A+/-; \operatorname{trk} B-/-, \operatorname{trk} A-/-; \operatorname{trk} C+/-, \operatorname{trk} A+/-$; trk $C-/-$ ) showed a small, approximately twofold, increase in pyknotic nuclei compared with wild-type mice, a value that was in most cases not significantly higher than in their corresponding single mutant mice. The observed pyknotic cells are likely to be granule neurons, because glial cells are rare in the granule cell layer of the dentate gyrus (Kosaka and Hama 1986; Rickmann et al. 1987). These findings indicate that TrkB and TrkC re-
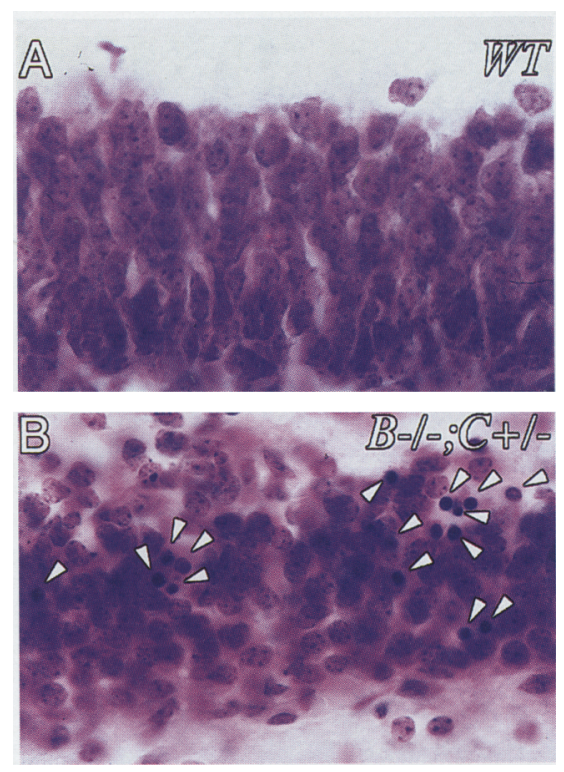

Figure 1. Morphology of pyknotic cells in the hippocampal dentate gyrus of trk double mutant mice. Representative Nisslstained $40-\mu \mathrm{m}$ coronal sections of the granule cell layer of the dentate gyrus of a P12 wild-type $(A)$ and a $\operatorname{trk} B-/-; \operatorname{trk} C+/-$ mutant mouse $(B)$. Note the typical appearance of pyknotic cells (arrowheads) in panel B with darkly stained condensed chromatin. Magnification, $1000 \times$.

ceptors cooperate in promoting the survival of dentate gyrus neurons in the postnatal brain.

\section{Dentate gyrus neurons require $\operatorname{Trk} B$ and $\operatorname{Trk} C$ after} the period of naturally occurring cell death

The majority of hippocampal granule cells are generated after birth in rodents and the peak of naturally occurring neuronal cell death occurs toward the end of the first postnatal week (Gould et al. 1991). We therefore characterized the kinetics of neuronal cell death in mice carrying mutant $\operatorname{trk} B$ and $\operatorname{trk} C$ alleles between birth and P12. At birth, the numbers of pyknotic cells were low in wild-type and all mutant mice analyzed (data not shown). At P6, the numbers of pyknotic cells within the dentate gyrus increased to similar levels in wild-type and trkB/trk $C$ mutant mice $[1032 \pm 123(n=3)$ and $1027 \pm 108$ $(n=5)$, respectively]. At $\mathrm{P} 9, \operatorname{trk} B-/-; \operatorname{trk} C+/-$ and $\operatorname{trk} B+/-; \operatorname{trk} C-/-$ mutant mice showed a significant, approximately fourfold increase in pyknotic nuclei compared with wild-type mice, whereas no such increase was observed in the single mutants (Fig. 2B). These results demonstrate that survival of dentate gyrus granule cells requires expression of TrkB and TrkC receptors shortly after the period of naturally occurring neuronal cell death.

\section{Hippocampal dentate gyrus neurons undergo apoptosis}

Because pyknotic nuclei are phagocytized within minutes, we employed a more sensitive method for the de- 

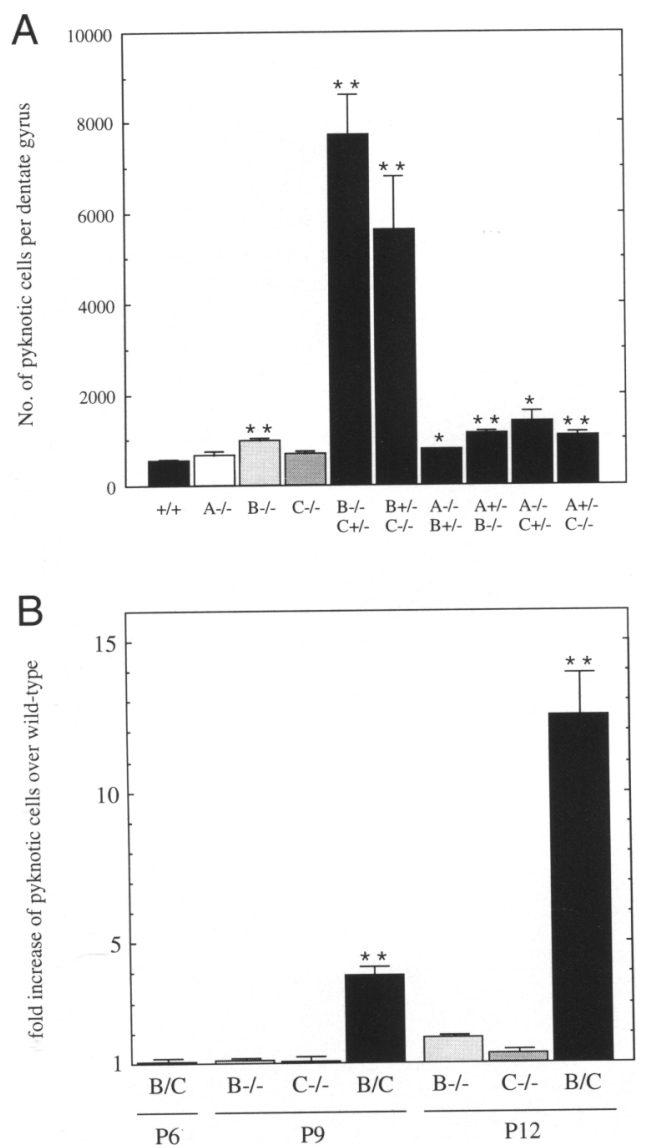

Figure 2. (A) Comparison of the number of pyknotic cells in the dentate gyrus of P12 wild-type $(+1+1$, single trkA-1$(\mathrm{A}-1-1, \operatorname{trk} B-1-(\mathrm{B}-/-1, \operatorname{trk} C-1-(\mathrm{C}-1-)$, and double mutant mice of the indicated genotype $($ e.g, $\mathrm{B}-1-; \mathrm{C}+1-$ for $\operatorname{trk} B-/-; \operatorname{trk} C+/-1$. The data were obtained from three to four mice of all genotypes. Values represent means and standard errors per dentate gyrus on hemisections of P12 mice. Statistical analysis was carried out using Student's $t$-test and is indicated where significant. $\left.\right|^{*}|P<0.01 ;|^{* *} \mid P<0.001$. $(B)$ Increase in number of pyknotic cells in mutant compared with wild-type dentate gyri in brains of P6, P9, and P12 mice. Data from $\operatorname{trk} B-1-; \operatorname{trk} C+1-$ and $\operatorname{trk} B+/-; \operatorname{trk} C-/-$ mice were combined. Each bar represents the means ( \pm S.E.) from four to seven animals.

tection of apoptotic cells, known as TUNEL staining, which is based on nick end-labeling of DNA fragments in situ (Gavrielli et al. 1992). As shown in Figure 3, TUNEL staining of $\operatorname{trk} B-/-; \operatorname{trk} C+/-$ and $\operatorname{trk} B+/-$; trk $C-/-$ brains showed a massive amount of apoptotic cells in the hippocampal dentate gyrus. Quantitative analysis revealed a very good correlation with the scores obtained from cresyl violet-stained sections /data not shown). In addition, scattered TUNEL-positive cells were observed in superficial layers of the cerebral cortex, striatum, thalamus, and hypothalamus. Interestingly, few if any TUNEL-positive cells were observed in the pyramidal layer of the hippocampus. In wild-type, trkB-/ - and trkC-/ - brains, TUNEL-positive cells were very rare, correlating well with the number of pyknotic cells in Nissl-stained sections. Combinations involving trkA mutant alleles together with either $\operatorname{trk} B$ or trkC did not result in significantly more apoptotic cells than in corresponding single mutants, neither in the dentate gyrus (Fig. 3) nor elsewhere in the brain (data not shown). These results demonstrate that, at least during early postnatal life, dentate gyrus neurons are most vulnerable to the lack of neurotrophin signaling compared with other forebrain neuron populations. Analysis by transmission electron microscopy revealed typical apoptotic granule cells with large areas of condensed nuclear chromatin in the brains of $\operatorname{trk} B-/-$; trk $C+/-$ mice (data not shown). These results indicate that hip-

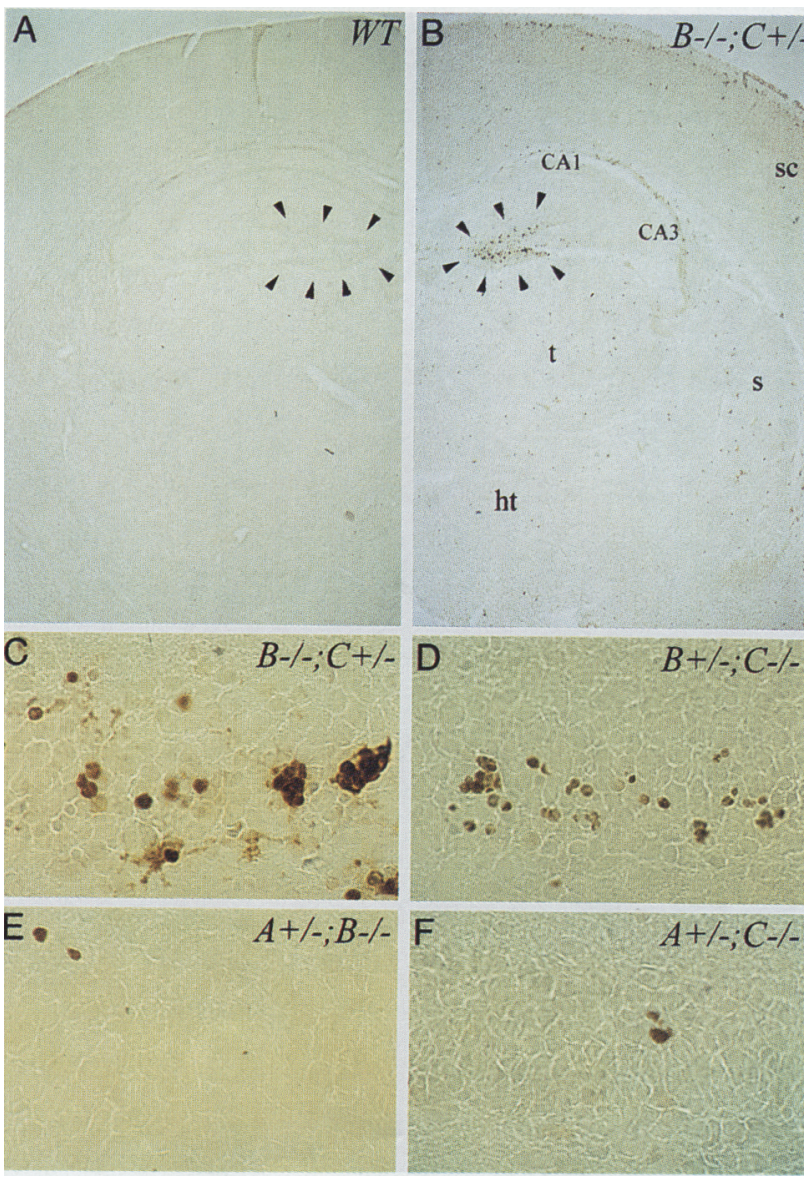

Figure 3. Increase in the number of TUNEL-positive dentate gyrus neurons in mice carrying mutant $\operatorname{trk} B$ and $\operatorname{trk} C$ alleles. Coronal sections from $\mathrm{P} 12$ wild-type $(A), \operatorname{trk} B-/-$; trk $C+/-$ $\mid B, C), \operatorname{trk} B+/-; \operatorname{trk} C-/-(D), \operatorname{trk} A+/-; \operatorname{trk} B-/-|E|$, trk $A+/-; \operatorname{trk} C-/-$ mice $(F)$ stained by the TUNEL technique. Note the massive amount of TUNEL-positive cells specifically in the hippocampal dentate gyrus in $B-D$ (the shape of the dentate gyrus is outlined by arrowheads in $A$ and $B \mid$. Pyramidal neurons of the hippocampus (CA1 through CA3 regions) lack significant numbers of TUNEL-positive cells. Scattered TUNEL-positive cells are seen in superficial layers of the somatosensory cortex $(\mathrm{sc})$, striatum $(\mathrm{s})$, thalamus $(\mathrm{t})$, and hypothalamus (ht). Magnification: $(A, B) 25 \times ;(C-F) 1000 \times$. 
pocampal granule cells of $\operatorname{trk} B / \operatorname{trk} C$ double mutant mice undergo programmed cell death.

\section{Reduced numbers of excitatory mossy fibers in the hippocampus of mice carrying mutant trkB and trkC alleles}

Dentate gyrus granule cells form excitatory connections, so-called mossy fibers, with CA3 pyramidal neurons, a pathway that is implicated in certain forms of long-term potentiation (Zalutsky and Nicoll 1990). As an indirect measure of function of the remaining viable granule cells in mice carrying mutant $\operatorname{trk} B$ and $\operatorname{trk} C$ alleles, we estimated the amount of mossy fibers projecting from the dentate gyrus to CA3 pyramidal neurons. We immunostained coronal sections for the $\mathrm{Ca}^{2+}$ binding protein calbindin (Celio 1990), which is a molecular marker for dentate gyrus granule cells and mossy fibers. The pattern of calbindin staining in single $\operatorname{trk} B-/-$ and $\operatorname{trk} C-/-$ mutant mossy fibers was indistinguishable from that in wild-type mice (Fig. 4 and data not shown). In contrast, both double $\operatorname{trk} B-/-$; $\operatorname{trk} C+/-$ (Fig. 4C) and $\operatorname{trk} B+/-$; trkC-/ - brains (not shown) reproducibly showed a

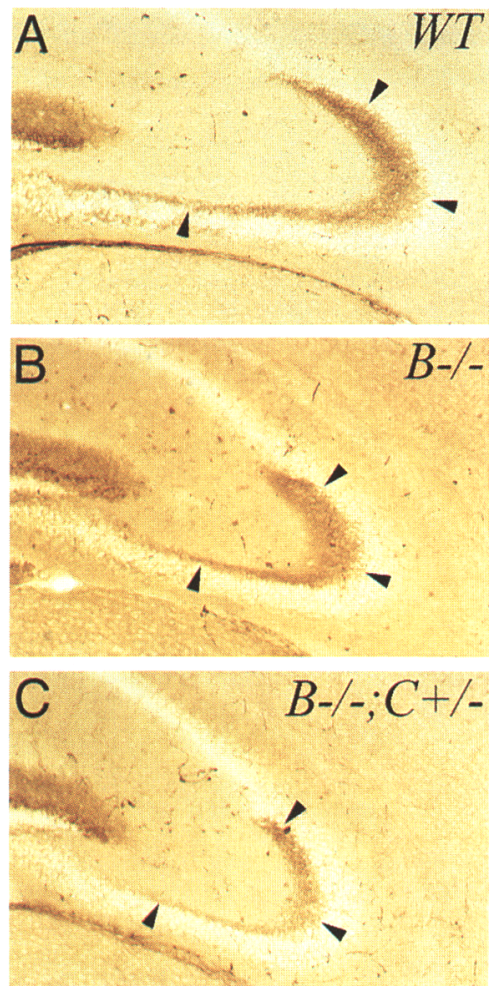

Figure 4. Reduced numbers of calbindin-positive mossy fibers projecting from dentate gyrus neurons in $\operatorname{trk} B / \operatorname{trk} C$ double mutant mice. Coronal sections from wild-type $(A), \operatorname{trk} B-/-(B)$, and $\operatorname{trk} B-1-; \operatorname{trk} C+/-(C)$, immunostained with a calbindinspecific antibody. Note the reduction of cross-sectional area of mossy fibers (indicated by arrowheads) in $\operatorname{trk} B-/-; \operatorname{trk} C+/-$ double mutants compared with wild-type and single mutant mice. marked reduction in calbindin positive mossy fibers. Using an image analysis program for quantitative analysis (Olivo et al. 1993), the cross-sectional area of calbindin positive mossy fibers was significantly reduced in $\operatorname{trk} B-/-; \operatorname{trk} C+/-(58 \%)$ and $\operatorname{trk} B+/-; \operatorname{trk} C-/-$ $(48 \%)$ brains, respectively, compared with wild-type, and $\sim 40 \%$ compared with the single mutants (Table 1 ). Because the brains of $\operatorname{trk} B-/-$; trk $C+/-$ and $\operatorname{trk} B+/-$; $\operatorname{trk} C-/$ - were not significantly smaller than those of the corresponding single mutants (data not shown), the reduction in mossy fibers is likely to be a consequence of the dramatic increase in cell death in the dentate gyrus. In contrast, the $20 \%$ reduction in cross-sectional area of mossy fibers in the single mutants is in part a result of the $20-25 \%$ smaller brain size of mutant versus wildtype brains. Mice carrying combinations of mutant $t r k A$ alleles with either mutant $\operatorname{trk} B$ or $\operatorname{trk} C$ alleles did not show a significant reduction of mossy fibers (data not shown). These results indicate that TrkB and TrkC receptors cooperate in maintaining the efferent projections of dentate granule cells to $\mathrm{CA} 3$ pyramidal neurons.

\section{Cerebellar granule cells require TrkB and TrkC receptors for survival}

Analysis of cresyl violet-stained sagittal sections of P12 cerebella derived from trkB/trkC double mutant mice revealed an enlargement of the external granule layer (EGL), a zone where granule cell precursors divide and undergo the initial phase of neuronal differentiation (see Fig. 7 , below). Both $\operatorname{trk} B-/-$; $\operatorname{trk} C+/-$ and $\operatorname{trk} B+/-$; trk $C-1-$ mice had 40 and $50 \%$ more EGL neurons, respectively, compared with wild-type mice (data not shown; $n=3$ for each genotype; $P<0.01$ ). In contrast, $\operatorname{trk} B-/$ - and trkC - / - single mutants showed a small, yet not significant increase in the numbers of EGL neurons compared with wild-type cerebella (data not shown). The numbers of pyknotic cells in the EGL of trkB-/- and trkC-/- single mutants were also slightly elevated compared with wild-type mice (Fig. 5). Surprisingly, the numbers of pyknotic cells in $\operatorname{trk} B-/-$; $\operatorname{trk} C+/-$ and $\operatorname{trk} B+/-$;trkC $-/-$ double mutants were increased 7.5- and 6-fold, respectively, compared with wild-type mice and 5- and 5.5-fold, respectively, compared with $\operatorname{trk} B-/-$ and $\operatorname{trk} C-/-$ mice (Fig. 5). Likewise, TUNEL staining revealed a marked increase in apoptotic cells in sections derived from mice carrying mutant $\operatorname{trk} B$ and $\operatorname{trk} C$ alleles compared with wild-type or single mutants (Fig. 6 and data not shown). Interestingly, the internal granule layer (IGL), which contains fully differentiated granule cells after their migration through the molecular layer, did not contain significant numbers of TUNEL-positive or pyknotic cells in mice with mutant $\operatorname{trk} B$ and $\operatorname{trk} C$ alleles (data not shown). These results indicate that TrkB and TrkC receptors cooperate in promoting survival of premigratory cerebellar granule cells. 
Table 1. Reduction of calbindin-positive mossy fibers in trkB/trkC double mutant mice

\begin{tabular}{|c|c|c|c|c|}
\hline Genotype & No. of animals & $\begin{array}{l}\text { Surface of calbindin }{ }^{+} \\
\text {mossy fibers } \pm \text { S.E.M. } \\
\left(\times 1000 \mu \mathrm{m}^{2}\right)\end{array}$ & $\begin{array}{l}\text { Reduction compared } \\
\text { with wild-type } \\
(\%)\end{array}$ & $\begin{array}{l}\text { Reduction compared } \\
\text { with single mutants } \\
(\%)\end{array}$ \\
\hline Wild-type & 3 & $126 \pm 10$ & & \\
\hline $\operatorname{trk} B-1-$ or $\operatorname{trk} C-1-$ & 4 & $102 \pm 7$ & 20 (n.s.) & \\
\hline $\operatorname{trk} B-/-; \operatorname{trk} C+/-$ & 4 & $53 \pm 4$ & $58^{\mathrm{a}}$ & $43^{a}$ \\
\hline $\operatorname{trk} B+/-; \operatorname{trk} C-/-$ & 3 & $66 \pm 3$ & $48^{\mathrm{b}}$ & $40^{\mathrm{b}}$ \\
\hline
\end{tabular}

The cross-sectional area of calbindin-positive mossy fibers was measured using an image analysis program (Olivo et al. 1993), and the average value was taken from two hemisections per animal. Values represent mean \pm standard errors from the indicated number of animals. Values for single mutant mice were combined. No statistical difference was observed between single mutants. Statistical analysis was carried out using Student's $t$-test. n.s.: not significant.

${ }^{\mathrm{a}} P<0.001$.

${ }^{\mathrm{b}} P<0.01$.

\section{Redundant function of TrkB and TrkC receptors in Purkinje cell differentiation, but not survival}

The second major cell type of the cerebellum, the Purkinje cell, was next analyzed for its survival in $\operatorname{trk} B$ and trk $C$ single and double mutants. In contrast to cerebellar granule neurons of the EGL, no significant numbers of pyknotic Purkinje cells were observed in either $\operatorname{trk} B-/-$; $\operatorname{trk} C+/-$ or $\operatorname{trk} B+/-$; trkC $-/-$ mice (data not shown). Moreover, the total number of Purkinje cells was unchanged in $\operatorname{trk} B / \operatorname{trk} C$ double mutant mice compared with the single mutant and wild-type mice /data not shown). Instead, sections stained for calbindin revealed a marked decrease in the highly branched dendritic trees of Purkinje cells in mice carrying mutant

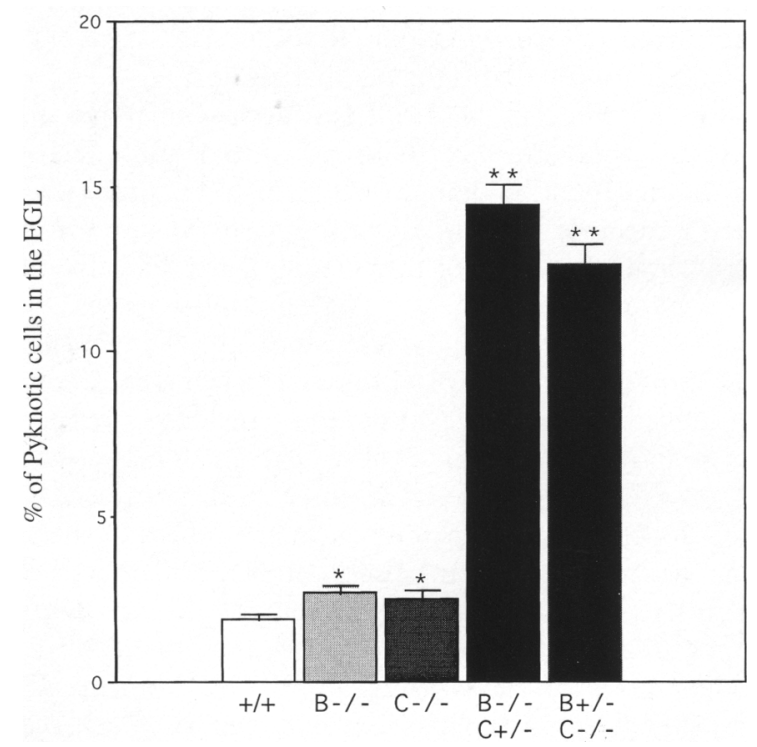

Figure 5. Premigratory cerebellar granule cells depend on TrkB and TrkC for survival. Percentage of pyknotic cells (means \pm S.E.) in the EGL in cresyl violet-stained mid-sagittal sections of P12 mice. The data were obtained from three mice of all genotypes. For abbreviations, see Fig. 2. Statistical analysis was carried out using Student's $t$-test and is indicated where significant. $\left.\left(^{\star}\right) P<0.01 ; 1^{\star \star}\right) P<0.001$. $\operatorname{trk} B$ and $\operatorname{trk} C$ alleles (Fig. 7) The thickness of dendritic trees was reduced by $50 \%$ and $48 \%$ in $\operatorname{trkB}-/-$; $\operatorname{trk} C+/-$ and $\operatorname{trk} B+/-; \operatorname{trk} C-/-$ mice, respectively (Table 2). Both trkB-/- and trk $C-/-$ single mutants showed mild, yet significant reductions in dendritic arborizations. These results indicate that Purkinje cell survival is much less sensitive to reduced levels of TrkB and TrkC compared with granule cell survival. Purkinje cell survival may therefore depend on trophic signals distinct from neurotrophins. In contrast, Purkinje cell dendritic differentiation directly or indirectly depends on cooperative signaling via TrkB and TrkC.

\section{Discussion}

This study provides genetic evidence for a physiological role of endogenous neurotrophins in the survival of two

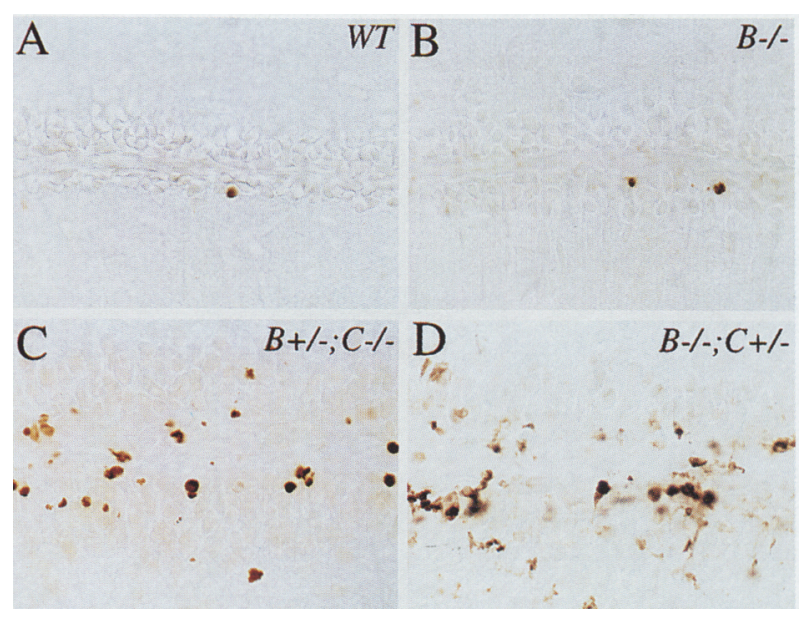

Figure 6. Increase in the number of TUNEL-positive cerebellar granule cells in mice carrying mutant $\operatorname{trk} B$ and $\operatorname{trk} C$ alleles. Mid-sagittal section of cerebella from P12 wild-type $(A), \operatorname{trk} B-/-(B), \operatorname{trk} B+/-; \operatorname{trk} C-/-(C)$, and $\operatorname{trk} B-/-$; trk $C+/-$ mice $(D)$ stained by the TUNEL technique. Note the massive increase in tunel-positive cells in the external granule layer of mice with mutant $\operatorname{trk} B$ and $\operatorname{trk} C$ alleles. Magnification, $1000 \times$. 


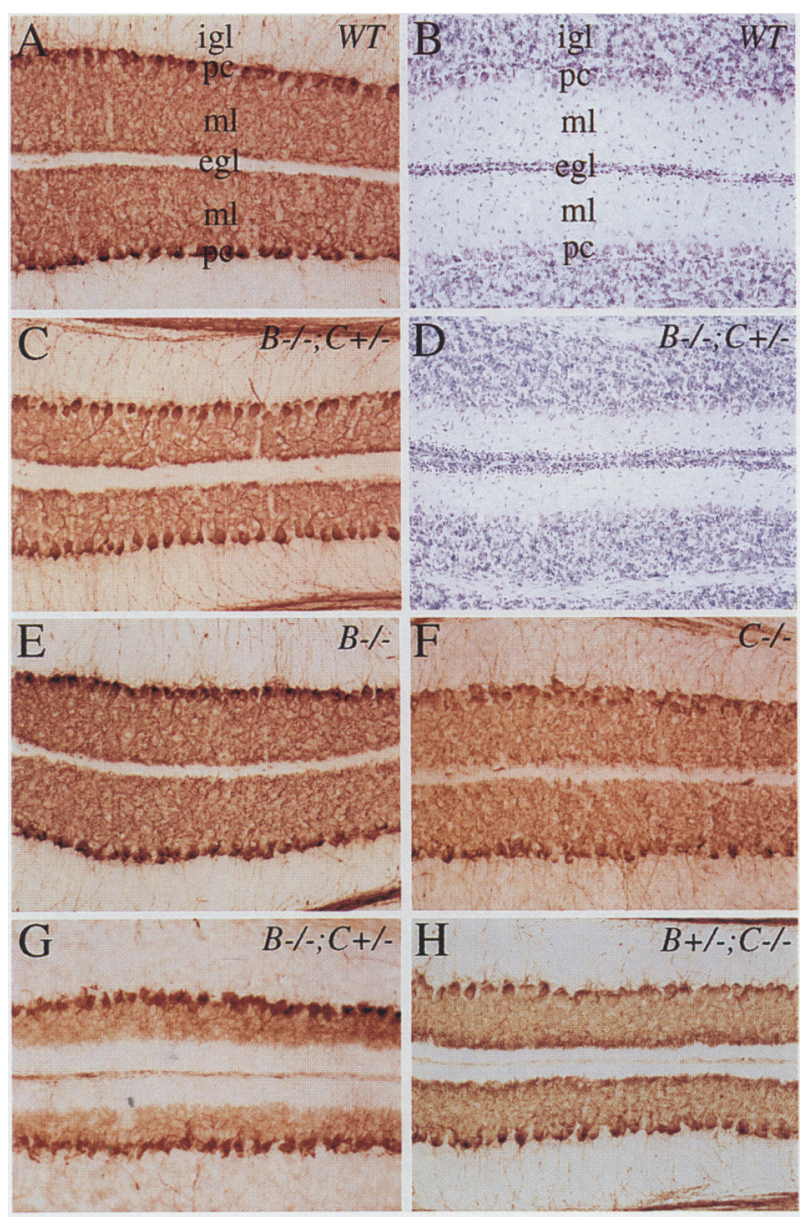

Figure 7. Cerebellar Purkinje cells survive normally, but have reduced dendritic trees in mice carrying mutant $\operatorname{trk} B$ and $\operatorname{trk} C$ alleles. Mid-sagittal sections from P12 wild-type $(A), \operatorname{trk} B-/-$; $\operatorname{trk} C+/-(C, G), \operatorname{trk} B-/-(E), \operatorname{trk} C-/-(F)$, and $\operatorname{trk} B+/-$; trkC-/- mice $(H)$ immunostained with a calbindin-specific antibody. Note the significant reduction of dendritic arborizations in two different $\operatorname{trk} B-/-; \operatorname{trk} C+/-(C, G)$ and one $\operatorname{trk} B+1-$;rk $C-/-$ mutant $(H)$ compared with the single mutants. To visualize the increase in the number of granule cells in the EGL of $t r k B-/-$; trkC $+/$ - compared with wild-type mice, cresyl violet-stained sections were included $(D$ and $B$, respectively). (egl) External granule layer; (igl) internal granule layer; (ml) molecular layer; (pc) purkinje cell layer. Magnification, $200 \times$.

populations of central neurons, namely, hippocampal and cerebellar granule cells. Moreover, TrkB and TrkC receptors, which are coexpressed in these neurons (Klein et al. 1990; Bengzon et al. 1993; Lamballe et al. 1994; Tessarollo et al. 1993; Lindvall et al. 1994; Segal et al. 1995), act in a redundant fashion, indicating that activation of either of the two receptors is sufficient for survival. The dramatic increase in cell death in P12 $\operatorname{trk} B-/-; \operatorname{trk} C+/-$ and trk $B+/-; \operatorname{trk} C-/-$ mice is remarkable considering the fact that these cells still carry one functional allele of either the $\operatorname{trk} B$ or $\operatorname{trk} C$ gene. Similar effects of Trk receptor dosage have been observed recently in vitro during the analysis of the survival-promoting effects of NT3 on primary sensory neurons derived from crosses of double heterozygous trk mutant mice (Davies et al. 1995). Hippocampal and cerebellar granule neurons are the first examples of cells in which two different neurotrophin receptors act in a directly compensating, redundant fashion. Thus, these neurons can survive in vivo in the presence of either the TrkB ligands (BNDF and NT4/5) or the TrkC ligand (NT3), but have no other source of survival factors. Other CNS neuron, such as motoneurons, which respond very well to exogenous neurotrophins (Oppenheim et al. 1992; Sendtner et al. 1992; Yan et al. 1992; Henderson et al. 1993), survive even in the absence of both TrkB and TrkC receptors (L. Minichiello, F. Piehl, and R. Klein, unpubl.), indicating that they can use other trophic factors distinct from neurotrophins.

Our findings in the CNS are in sharp contrast to most peripheral neurons, which critically depend on a single neurotrophin/Trk receptor signaling pathway. Hence, the effects on peripheral neuron survival of combined deficiencies in either Trk receptors (Minichiello et al. 1995) or neurotrophins (Ernfors et al. 1995) are generally additive and indicate that neurotrophins act in a largely noncompensatory and nonredundant fashion. This suggests that the survival of most peripheral neurons may follow different mechanisms than central neurons. For instance, the survival of peripheral sensory neurons of the vestibular ganglion is regulated by limiting amounts of the TrkB ligand BDNF, as demonstrated in mice heterozygous for a BDNF null allele (Bianchi et al. 1996). In the CNS, it remains to be determined whether or not the numbers of granule neurons are also regulated by limiting amounts of TrkB and TrkC ligands. It is hoped that mice triple heterozygous for BDNF, NT3, and NT4/5 null alleles will shed light on this issue.

Some populations of peripheral neurons behave in exactly the opposite way to hippocampal and cerebellar granule neurons, in that they appear to require two different neurotrophin/Trk signaling pathways for survival during development. For instance, essentially all sympathetic neurons require NGF/TrkA, and $\sim 50 \%$ also require NT3 for survival (Crowley et al. 1994; Farinas et al. 1994; Smeyne et al. 1994). Likewise, a fraction of vestibular neurons requires $\mathrm{TrkC}$, but the same reduction of vestibular neurons is observed in $\operatorname{trk} B-/-$ and $\operatorname{trk} B-/-$; trk $C-/-$ mutant mice, indicating that the TrkC-dependent population was also affected in the $\operatorname{trk} B$ single mutant mice (Minichiello et al. 1995). Whether or not this reflects a simultaneous dependence or a sequential requirement because of a switch in neurotrophin dependence (Davies 1994b) remains to be determined. In any case, direct compensation between two Trk receptors has not been observed in any peripheral neuron population.

Our results provide genetic support for current hypotheses on neurotrophin function in the hippocampus. Most neurotrophins and the receptors TrkB and TrkC are coexpressed in the dentate gyrus and their expression is markedly increased as a result of brain insults, suggest- 
Table 2. Reduced dendritic differentiation of cerebellar Purkinje cells in trkB/trkC double mutant mice

\begin{tabular}{|c|c|c|c|c|}
\hline Genotype & No. of animals & $\begin{array}{l}\text { Length of dendritic } \\
\text { tree } \pm \text { S.E.M. }(\mu \mathrm{m})\end{array}$ & $\begin{array}{l}\text { Reduction compared } \\
\text { with wild-type } \\
(\%)\end{array}$ & $\begin{array}{l}\text { Reduction compared } \\
\text { with single mutants } \\
|\%|\end{array}$ \\
\hline Wild-type & 4 & $143 \pm 6.5$ & & \\
\hline $\operatorname{trk} B-/-$ & 4 & $111 \pm 6.5$ & $22^{a}$ & \\
\hline $\operatorname{trk} C-1-$ & 4 & $115 \pm 8$ & $19^{a}$ & \\
\hline $\operatorname{trk} B-1-; \operatorname{trk} C+1-$ & 5 & $72 \pm 6.5$ & $50^{\mathrm{b}}$ & $36^{\mathrm{b}}$ \\
\hline $\operatorname{trk} B+/-; \operatorname{trk} C-1-$ & 6 & $75 \pm 2.5$ & $48^{\mathrm{b}}$ & $35^{\mathrm{b}}$ \\
\hline
\end{tabular}

Measurements on the length of dendritic trees of Purkinje cells were performed on calbindin-stained mid-sagittal sections of P12 mice (see Fig. 7). The mean length of dendritic trees, expressed in micrometers, was determined by measuring the thickness of the molecular layer on both sides of each of three different lobes per cerebellum on the above-indicated number of animals. Statistical analysis was carried out using Student's $t$-test.

${ }^{\mathrm{a}} P<0.01$.

${ }^{\mathrm{b}} P<0.001$.

ing, together with other findings, that neurotrophin signaling may protect against neuronal damage by inducing sprouting and synaptic reorganization (Lindvall et al. 1994; Isackson 1995). The fact that TrkB and TrkC mediate a physiological survival signal makes it very likely that they also have a similar role in pathophysiological conditions that threaten neuronal viability. Hippocampal pyramidal neurons have been shown in vitro to survive independently of the ligands of TrkB and TrkC receptors (Collazo et al. 1992; Ip et al. 1993; Ohsawa et al. 1993). In trkB/trkC double mutants, no significant apoptosis was detected in the Ammon's horn, where hippocampal pyramidal neuron cell bodies are located. In contrast, the survival of dentate gyrus neurons was enhanced by BDNF and NT3 in vitro (Lowenstein and Arsenault 1996), consistent with the observed selective vulnerability of dentate gyrus neurons in $\operatorname{trk} B-/-$; trk $C+/$ - and $\operatorname{trk} B+/-; \operatorname{trk} C-/-$ mutant mice.

The kinetic analysis of cell death in $\operatorname{trk} B / \operatorname{trk} C$ double mutants revealed that dentate gyrus neurons require TrkB and TrkC receptors shortly after the period of naturally occurring cell death. TrkB and TrkC therefore do not appear to have a role during the initial proliferative phase, as we have shown recently for TrkB in the trigeminal system (Piñon et al. 1996). In this respect, dentate gyrus neurons behave more similarly to sensory neurons of the vestibular ganglion, which require TrkB receptors for survival after their axons have reached the target organ (Schimmang et al. 1995). Therefore, rather than supporting the survival of proliferating neuronal precursors, TrkB and TrkC appear to be mainly required to support postmitotic dentate granule cells and their excitatory synaptic connections within the hippocampus.

We found an inverse correlation between the number of apoptotic cells in the dentate gyrus and the crosssectional area of calbindin-positive mossy fibers, suggesting that the number of functional granule cells was also reduced in $\operatorname{trk} B / \operatorname{trk} C$ double mutant mice. In addition to a reduction in cross-sectional area of mossy fibers, the intensity of calbindin staining appeared reduced in most double mutants (not shown) consistent with earlier reports on BDNF $-/$ - mice (Jones et al. 1994) and with enhanced calbindin expression in neurotrophin treated cultures (Collazo et al. 1992; Ip et al. 1993). Whether or not calbindin has a physiological role in mediating the survival function of neurotrophins, possibly by stabilizing $\mathrm{Ca}^{2+}$ homeostasis (Lindvall et al. 1994), remains to be determined. Also, because of the limited life span of the animals analyzed above, we do not know whether eventually all dentate gyrus neurons would undergo cell death, or whether only a calbindin-positive subpopulation is affected.

A remarkably similar picture was observed in the cerebellum. Like dentate gyrus granule neurons, cerebellar granule neurons coexpress TrkB and TrkC, but not TrkA receptors, and respond to exogenous neurotrophins in culture, albeit to varying degrees. Whereas BDNF and NT4/5 promote the survival of cultured granule neurons, NT3 appears to induce more subtle responses including induction of c-Fos and change in neurite outgrowth (Segal et al. 1992, 1995; Leingärtner et al. 1994; Gao et al. 1995). The fact that both $\operatorname{trk} B+/-; \operatorname{trk} C-/-$ and $\operatorname{trk} B-/-$; trk $C+/-$ mice show marked increases in numbers of apoptotic granule neurons suggests that the endogenous ligands of TrkB and TrkC are equally important for the survival of postnatal cerebellar granule neurons. Interestingly, cerebellar granule neurons appear to require TrkB and TrkC mediated signaling before descending from the EGL to the IGL. These findings are consistent with previous observations in organotypic cultures, where BDNF induced c-Fos in the EGL, but not in the IGL or Purkinje cell layer (Segal et al. 1992). Moreover, TrkB expression was shown to be down-regulated in IGL neurons as compared with migrating granule cells (Gao et al. 1995). Together, these results suggest that cerebellar granule neurons, once fully matured and situated in the IGL, become independent of endogenous neurotrophins presumably by up-regulating receptors for other trophic factors.

In contrast to granule neurons, the survival of Purkinje cells was not affected in $\operatorname{trk} B-/-; \operatorname{trk} C+/-$ and $\operatorname{trk} B+/-; \operatorname{trk} C-/-$ mice. This suggests that either the critical levels of $\mathrm{TrkB} / \mathrm{C}$ signaling are much lower for Purkinje cells, or that endogenous neurotrophins do not 
promote Purkinje cell survival. Instead, the maturation of Purkinje cell dendrites was markedly reduced in $\operatorname{trk} B-/-; \operatorname{trk} C+/-$ and $\operatorname{trk} B+/-; \operatorname{trk} C-/-$ mice compared with wild-type and single mutants. It is known that Purkinje cell dendritic differentiation is regulated to a major extent by contacts with the parallel fibers of granule neurons (Altman 1982: Baptista et al. 1994), rather than by intrinsic factors. Considering the degree of cell death in cerebellar granule neurons, it is possible that the observed reduction in dendritic arborization is indirectly a result of reduced interactions between granule and Purkinje cells. Alternatively, neurotrophins may have a direct role in promoting Purkinje cell differentiation. NT3 produced by cerebellar granule neurons has been shown to induce neurite sprouting of cultured Purkinje cells (Lindholm et al. 1993), implicating NT3 as one of the factors promoting Purkinje cell differentiation.

In summary, we have shown that, contrary to current belief, neurotrophins are important for the survival of at least two major CNS neuron populations. Whether or not other CNS neurons depend on endogenous neurotrophins for survival will require new longer-lived mouse models in which the expression of Trk receptors can be regulated tissue-specifically and/or temporally.

\section{Materials and methods}

\section{Mouse mutants}

The generation and genotypic analysis of $\operatorname{trk} A, \operatorname{trk} B$, and $\operatorname{trk} C$ mutant mice has been described previously (Klein et al. 1993, 1994; Smeyne et al. 1994; Schimmang et al. 1995). The phenotypes of double mutants were analyzed in a mixed $129 \times \mathrm{C} 57 \mathrm{Bl} / 6$ background.

\section{Histology}

Double heterozygous mutant mice were crossed and their litters fixed by cardiac perfusion at the indicated time points with $4 \%$ paraformaldehyde in $0.1 \mathrm{M}$ phosphate buffer. Prior to fixation, tail biopsies were taken for genotypic analysis. Brains were dissected, postfixed for $24 \mathrm{hr}$, left in sucrose until they sank to the bottom of the tube, mounted in tissue freezing medium (Tissue-Tek), and then frozen on dry ice.

\section{Hippocampus}

Serial cryosections were taken at a thickness of $40 \mu \mathrm{m}$ and further processed as described (Minichiello et al. 1995) in order to do free-floating immunohistochemistry and Nissl and TUNEL staining on the same animals. For quantitative analysis, Nissl-stained hemisections were selected from three areas, rostral, middle, and temporal dentate gyrus (Gould et al. 1991), and the numbers of pyknotic cells counted at $1000 \times$ magnification in the supra- and infrapyramidal blades of the granule cell layer. The hilus of the dentate gyrus was excluded from this analysis, as it contains other cell types than granule cells. Because the numbers of pyknotic cells of the three levels of the dentate gyrus were not significantly different within the same animal (data not shown), the total number of pyknotic cells per dentate gyrus was estimated by multiplying the average cell count by the number of sections between the most rostral and the most temporal sections. Because of the smaller size of mutant brains, the average number of $40-\mu \mathrm{m}$ sections was 37 and 27 , for wild-type and mutant P12 brains, respectively. The total number of dentate gyrus neurons was found to be reduced by $15-25 \%$ in P12 mutants compared with wild-type mice /data not shown). Because this correlated well with the $\sim 20-25 \%$ smaller brain size of mutant mice, the numbers of pyknotic cells were reported without correcting for the total number of dentate gyrus neurons.

\section{Cerebellum}

Serial cryosections were taken at a thickness of $8 \mu \mathrm{m}$ and cresyl violet Nissl-stained mid-sagittal sections were selected for analysis. The percentage of pyknotic cells in the EGL was determined on $\sim 2000$ healthy cells ( $n=3$ for each genotype) counted in three different cerebellar lobes (lobes IV, V, an VI), although similar numbers of pyknotic cells were present in all cerebellar lobes. The length of the dendritic tree of Purkinje cells was determined (using an ocular micrometer) by measuring the thickness of the molecular layer on both sides each of three different lobes per cerebellum on two adjacent mid-sagittal sections stained with calbindin (see below) on four to six animals per genotype.

\section{TUNEL staining}

Forty-micrometer coronal floating sections were postfixed with $4 \%$ paraformaldehyde, endogenous peroxide was blocked with $2 \% \mathrm{H}_{2} \mathrm{O}_{2}$, and the tissue was permeabilized in $0.3 \%$ triton $\mathrm{X}-100,0.1 \%$ sodium citrate. TUNEL staining was performed according to manufacturer's specifications (Boehringer). After incubation with a secondary biotinylated antibody and the $A B C$ reagent, peroxidase was reacted with $0.05 \%$ diaminobenzidine tetrahydrochloride and $0.003 \%$ hydrogen peroxide.

\section{Calbindin immunostaining}

Forty-micrometer coronal sections were pretreated as described (Minichiello et al. 1995). Goat anticalbindin antibodies (Sigma) were incubated (1:400 dilution) in Tris-buffered saline, containing $0.5 \%$ Triton $\mathrm{X}-100$ and $1 \%$ normal goat serum. Staining with the $A B C$ method was as described in legend of Figure 2.

\section{Acknowledgments}

We thank J.-C. Olivo for help with image analysis; G. Griffith and A. Habermann for help with electron microscopy; D. Lindholm and coworkers for the advice during the initial phase of this project; and A.M. Davies, C.E. Henderson, T. Graf, G. Lemke, and members of the Klein lab for critically reading the manuscript. L.M. is supported by a long-term postdoctoral European Molecular Biology Organization fellowship.

The publication costs of this article were defrayed in part by payment of page charges. This article must therefore be hereby marked "advertisement" in accordance with 18 USC section 1734 solely to indicate this fact.

\section{References}

Altman, J. 1982. Morphological development of the rat cerebellum and some of its mechanisms. In The cerebellum-New vistas (ed. S.L. Palay and V. Chan-Palay), pp. 8-46. SpringerVerlag, Berlin, Germany.

Arenas, E. and H.J. Persson. 1994. Neurotrophin-3 prevents the 
death of adult central noradrenergic neurons in vivo. Nature 367: 368-371.

Baptista, C.A., M.E. Hatten, R. Blazeski, and C.A. Mason. 1994. Cell-cell interactions influence survival and differentiation of purified Purkinje cells in vitro. Nature 12: 243-260.

Barbacid, M. 1995. Neurotrophic factors and their receptors. Curr. Opin. Cell Biol. 7: 148-155.

Bengzon, J., Z. Kokaia, P. Ernfors, M. Kokaia, G. Leanza, O.G. Nilsson, H. Persson, and O. Lindvall. 1993. Regulation of neurotrophin and trkA, trkB and trkC tyrosine kinase receptor messenger RNA expression in kindling. Neuroscience 53: 433-446.

Bianchi, L.M., J.C. Conover, B. Fritzsch, T. DeChiara, R.M. Lindsay, and G.D. Yancopoulos. 1996. Degeneration of vestibular neurons in late embryogenesis of both heterozygous and homozygous BDNF null mutant mice. Development 122: 1965-1973.

Cabelli, R.J., A. Hohn, and C.J. Shatz. 1995. Inhibition of ocular dominance column formation by infusion of NT-4/5 or BDNF. Science 267: 1662-1665.

Celio, M.R. 1990. Calbindin D-28K and parvalbumin in the rat nervous system. Neuroscience 35: 375-475

Cohen-Cory, S. and S.E. Fraser. 1995. Effects of brain-derived neurotrophic factor on optic axon branching and remodeling in vivo. Nature 378: 192-196.

Collazo, D., H. Takahashi, and R.D. McKay. 1992. Cellular targets and trophic functions of neurotrophin- 3 in the developing rat hippocampus. Neuron 9: 643-656.

Crowley, C., S.D. Spencer, M.C. Nishimura, K.S. Chen, S. PittsMeek, M.P. Armanini, L.H. Ling, S.B. McMahon, D.L. Shelton, A.D. Levinson, and H.S. Phillis. 1994. Mice lacking nerve growth factor display perinatal loss of sensory and sympathetic neurons yet develop basal forebrain cholinergic neurons. Cell 76: 1001-1011.

Davies, A.M. 1994a. Role of neurotrophins in the developing nervous system. J. Neurobiol. 25: 1334-1348.

- 1994b. Switching neurotrophin dependence. Curr. Biol. 4: $273-276$

Davies, A.M., L. Minichiello, and R. Klein. 1995. Developmental changes in NT3 signalling via TrkA and TrkB in embryonic neurons. EMBO J. 14: 4482-4489.

Eide, F.F., D.H. Lowenstein, and L.F. Reichardt. 1993. Neurotrophins and their receptors-Current concepts and implications for neurologic disease. Exp. Neurol. 121: 200-214.

Ernfors, P., T. Van De Water, J. Lorin, and R. Jaenisch. 1995. Complementary roles for BDNF and NT3 in vestibular and auditory development. Neuron 14: 1153-1164.

Farinas, I. and L.F. Reichardt. 1996. Neurotrophic factors and their receptors: Implications of genetic studies. Semin. Neurosci. (in press).

Farinas, I., K. Jones, C. Backus, X.-Y. Wang, and L. Reichardt. 1994. Severe sensory and sympathetic deficits in mice lacking neurotrophin-3. Nature 369: 658-661.

Gao, W.Q., J.L. Zheng, and M. Karihaloo. 1995. Neurotrophin4/5 (NT4/5) and brain-derived neurotrophic factor (BDNF) act at later stages of cerebellar granule cell differentiation. $J$. Neurosci. 15: 2656-2667.

Gavrielli, Y., Y. Sherman, and S.A. Ben-Sasson. 1992. Identification of programmed cell death in situ via specific labeling of nuclear DNA fragmentation. J. Cell Biol. 119: 493-501.

Götz, R., R. Kostner, C Winkler, F. Raulf, F. Lottspeich, M. Schartl, and $H$. Thoenen. 1994. Neurotrophin-6 is a new member of the nerve growth factor family. Nature 372: 266-269.

Gould, E., C.S. Woolley, and B.S. McEwen. 1991. Naturally occurring cell death in the developing dentate gyrus of the rat. J. Comp. Neurol. 304: 408-418.
Henderson, C.E. 1996. Role of neurotrophic factors in neuronal development. Curr. Opin. Neurobiol. 6: 64-70.

Henderson, C.E., W. Camu, C. Mettling, A. Gouin, K. Poulsen, M. Karlaloo, J. Rullamas, T. Evans, S.B. McMahon, M.P. Ar manini, L. Berkemeier, H.S. Phillips, and A. Rosenthal. 1993. Neurotrophins promote motor neuron survival and are present in embryonic limb bud. Nature 363: 266-270.

Ip, N., Y. Li, G.D. Yancopoulos, and R.M. Lindsay. 1993. Cultured hippocampal neurons show responses to BDNF, NT-3, and NT-4, but not NGF. J. Neurosci. 13: 3394-3405.

Isackson, P.J. 1995. Trophic factor response to neuronal stimuli or injury. Curr. Opin. Neurobiol. 5: 350-357.

Jones, K., I. Farinas, C. Backus, and L. Reichardt. 1994. Targeted disruption of the BDNF gene perturbs brain and sensory neuron development but not motor neuron development. Cell 76: 989-999

Kang, H. and E.M. Schuman. 1995. Long-lasting neurotrophininduced enhancement of synaptic transmission in the adult hippocampus. Science 267: 1658-1663.

Klein, R. 1994. Role of neurotrophins in mouse neuronal development. FASEB I. 8: 738-744.

Klein, R., D. Martin-Zanca, M. Barbacid, and L.F. Parada. 1990. Expression of the tyrosine kinase receptor gene $\operatorname{trk} B$ is confined to the murine embryonic and adult nervous system. Development 109: 845-850.

Klein, R., R.J. Smeyne, W. Wurst, L.K. Long, B.A. Auerbach, A.L. Joyner, and M. Barbacid. 1993. Targeted disruption of the trkB neurotrophin receptor gene results in nervous system lesions and neonatal death. Cell 75: 113-122.

Klein, R., I. Silos-Santiago, R.J. Smeyne, S.A. Lira, R. Brambilla, S. Bryant, L. Zhang, W.D. Snider, and M. Barbacid. 1994. Targeted disruption of $t r k C$, the neurotrophin-3 receptor gene, eliminates Ia muscle afferents and results in loss of proprioception. Nature 368: 249-251.

Kosaka, T. and K. Hama. 1986. Three-dimensional structure of astrocytes in the rat dentate gyrus. J. Comp. Neurol. 249: $242-260$

Lamballe, F., R.J. Smeyne, and M. Barbacid. 1994. Developmental expression of $t r k C$, the neurotrophin-3 receptor, in the mammalian nervous system. I. Neurosci. 14: 14-28.

Leingärtner, A., C.-P. Heisenberg, R. Kolbeck, H. Thoenen, and D. Lindholm. 1994. Brain-derived neurotrophic factor increases neurotrophin-3 expression in cerebellar granule neurons. J. Biol. Chem. 269: 828-830.

Lewin, G.R. and Y.-A. Barde. 1996. Physiology of the neurotrophins. Annu. Rev. Neurosci. 19: 289-317.

Lindholm, D., E. Castrén, P. Tsoulfas, R. Kolbeck, M. Berzaghi da Penha, A. Leingärtner, C-P. Heisenberg, L. Tessarollo, L.F. Parada, and H. Thoenen. 1993. Neurotrophin-3 induced by tri-iodothyronine in cerebellar granule cells promotes Purkinje cell differentiation. $J$. Cell Biol. 122: 443-45.

Lindvall, O., Z. Kokaia, J. Bengzon, E. Elmer, and M. Kokaia. 1994. Neurotrophins and brain insults. Trends Neurosci. 17: 490-496.

Lowenstein, D.H. and L. Arsenault. 1996. The effects of growth factors on the survival and differentiation of cultured dentate gyrus neurons. I. Neurosci. 16: 1759-1769.

Minichiello, L., F. Piehl, E. Vazquez, T. Schimmang, T. Hökfelt, J. Represa, and R. Klein. 1995. Differential effects of combined trk receptor mutations on dorsal root ganglion and inner ear sensory neurons. Development 121: 4067-4075.

Ohsawa, F., H.R. Widmer, B. Knusel, T.L. Denton, and F. Hefti. 1993. Response of embryonic rat hippocampal neurons in culture to neurotrophin-3, brain-derived neurotrophic factor and basic fibroblast growth factor. Neuroscience 57: 67-77.

Olivo, J.-C., I.-C. Izpisua-Belmonte, C. Tickle, C Boulin, and D. 


\section{Minichiello and Klein}

Duboule. 1993. Reconstruction from serial sections: A tool for developmental biology. Application to Hox genes expression in chicken wing buds. Bioimaging 1: 151-158.

Oppenheim, R.W., Y. Qin-Wei, D. Prevette, and Q. Yan. 1992. Brain-derived neurotrophic factor rescues developing avian motoneurons from cell death. Nature 360: 755-757.

Piñon, L.G.P., L. Minichiello, R. Klein, and A.M. Davies. 1996. Timing of neuronal death in trkA, trkB, and trkC mutant embryos demonstrates neurotrophin switching in developing trigeminal neurons. Development 122: 3255-3261.

Richmann, M., D.G. Amaral, and W.M. Cowan. 1987. Organization of radial glial cells during the development of the rat dentate gyrus. I. Comp. Neurol. 264: 449-479.

Schimmang, T., L. Minichiello, E. Vazquez, I. San Jose, F. Giraldez, R. Klein, and J. Represa. 1995. Developing inner ear sensory neurons require TrkB and TrkC receptors for innervation of their peripheral targets. Development 121: 33813391.

Segal, R.A, H. Takahashi, and R.D.G. McKay. 1992. Changes in neurotrophin responsiveness during the development of cerebellar granule neurons. Neuron 9: 1041-1052.

Segal, R.A., S.L. Pomeroy, and C.D. Stiles. 1995. Axonal growth and fasciculation linked to differential expression of BDNF and NT3 receptors in developing cerebellar granule cells. $J$. Neurosci. 15: 4970-4981.

Sendtner M., B. Holtmannn, R. Kolbeck, H. Thoenen, and Y.-A. Barde. 1992. Brain-derived neurotrophic factor prevents the death of motoneurons in newborn rats after nerve section. Nature 360: 757-759.

Smeyne, R.J., R. Klein, A. Schnapp, L.K. Long, S. Bryant, A. Lewin, S.A. Lira, and M. Barbacid. 1994. Severe sensory and sympathetic neuropathies in mice carrying a disrupted Trk/ NGD receptor gene. Nature 368: 246-249.

Snider, W. 1994. Function of the neurotrophins during nervous system development: What the knockouts are teaching us. Cell 77: 627-638.

Tessarollo, L., P. Tsoulfas, D. Martin-Zanca, D.J. Gilbert, ,N.A. Jenkins, N.C. Copeland, and L.F. Parada. 1993. trkC, a receptor of neurotrophin-3, is widely expressed in the developing nervous system and in non-neuronal tissues. Development 118: 463-475.

Thoenen, H. 1995. Neurotrophins and neuronal plasticity. Science 270: 593-598.

Yan, Q., J. Elliott, and W.D Snider. 1992. Brain-derived neurotrophic factor rescues spinal motor neurons from axotomyinduced cell death. Nature 360: 753-755.

Zalutsky, R.A. and R.A. Nicoll. 1990. Comparison of two forms of long-term potentiation in single hippocampal slices. Science 248: 1619-1624. 


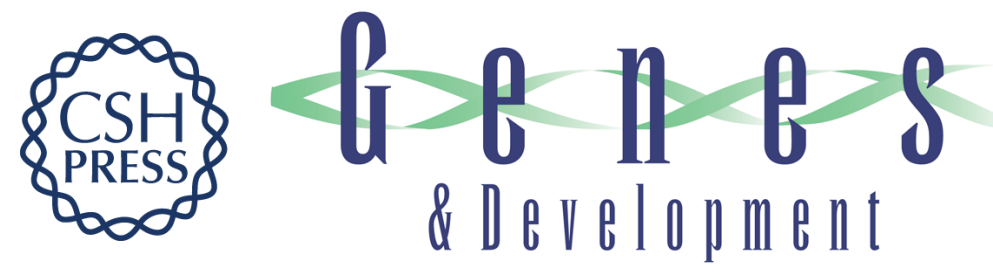

\section{TrkB and TrkC neurotrophin receptors cooperate in promoting survival of hippocampal and cerebellar granule neurons.}

L Minichiello and R Klein

Genes Dev. 1996, 10:

Access the most recent version at doi:10.1101/gad.10.22.2849

References This article cites 53 articles, 18 of which can be accessed free at:

http://genesdev.cshlp.org/content/10/22/2849.full.html\#ref-list-1

License

Email Alerting

Service

Receive free email alerts when new articles cite this article - sign up in the box at the top right corner of the article or click here.

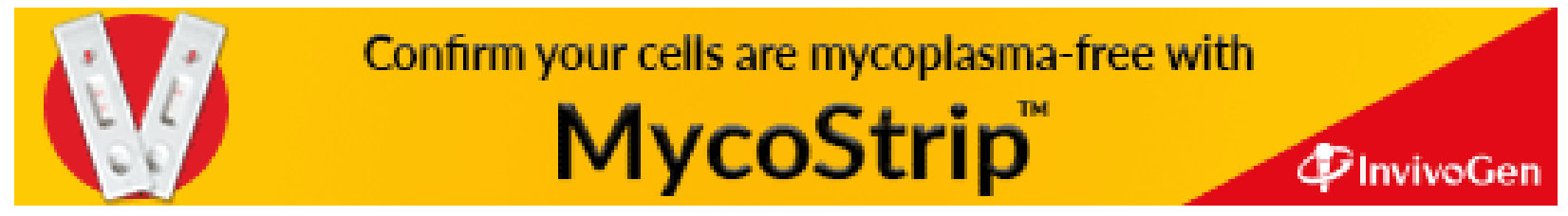

